\title{
DISSOCIATED NEURONS FROM NORMAL AND MUTANT DROSOPHILA LARVAL CENTRAL NERVOUS SYSTEM IN CELL CULTURE ${ }^{1}$
}

\author{
CHUN-FANG WU, ${ }^{*, 2}$ NOBUYUKI SUZUKI, ${ }^{*, 3}$ AND MU-MING POO \\ * Department of Zoology, University of Iowa, Iowa City, Iowa 52242 and $\ddagger$ Department of Physiology and Biophysics, California \\ College of Medicine, University of California, Irvine, Irvine, California 92717
}

Received October 29, 1982; Revised March 18, 1983; Accepted April 12, 1983

\begin{abstract}
A primary dissociated cell culture of Drosophila larval central nervous system is reported. Divisions of neuroblasts and vigorous outgrowth of neurites could be observed in culture. Within $24 \mathrm{hr}$ cultured cells exhibited characteristic neuronal morphology and unimpaired ability to synthesize and accumulate acetylcholine. This cell culture system renders easy access to experimental analysis of normal neuronal properties and the altered mechanisms in neurological mutants. Single-channel currents induced by acetylcholine and regenerative action potentials were studied in the somata of the dissociated neurons. The appearance of $\mathrm{Na}$ channels in these cultured neurons was demonstrated by the cell lethality induced by veratridine and inhibition of the effect by tetrodotoxin. Dissociated neurons from a temperature-sensitive paralytic mutant nap ${ }^{t s}$, in which nerve conduction fails at high temperature, were studied in culture. Neuronal growth was not affected by this mutation, nor by tetrodotoxin. However, $n a p^{t s}$ neurons showed greatly reduced sensitivity to veratridine even at $21^{\circ} \mathrm{C}$, a temperature at which nap $p^{t s}$ individuals behave normally. This finding indicates expression of the $n a p^{t s}$ phenotype at a level of isolated single cells and provides independent evidence that $n a p^{t s}$ affects $\mathrm{Na}$ channel function.
\end{abstract}

Single-gene mutations can produce specific effects on the nervous system (Benzer, 1973; Pak and Pinto, 1976). In the fruitfly, Drosophila melanogaster, there are available a number of behavioral mutants with altered neuronal physiology (Ikeda et al., 1976; Siddiqi and Benzer, 1976; Jan et al., 1977; Jan and Jan, 1978; Wu et al., 1978; Ganetzky and $\mathrm{Wu}, 1982 \mathrm{a}$ ) or morphology (Heisenberg et al., 1978). Analysis of the nervous systems of these mutants at a cellular level can lead to new insights into mechanisms underlying neuronal development and functions.

In vitro cell culture systems allow continuous observations on isolated cells under experimental manipulations and are ideal for characterizing the normal neu-

\footnotetext{
${ }^{1}$ We thank Mr. J. M. Berneking, Ms. A. Mohler, and Ms. G. R Zuercher for technical assistance, and Drs. D. L. Barker, B. Ganetzky, $\mathrm{S}$. B. Kater, and M. Tanouye for comments on the manuscript. We gratefully acknowledge the help of Drs. M. A. Tanouye and S. H. Young in the single channel studies. This work was supported by Public Health Service Grants NS15350, NS15797, and NS00675 and a grant from the Chicago Community Trust/Searle Scholar Program to C. -F. W.

${ }^{2}$ To whom correspondence should be addressed.

${ }^{3}$ Present address: Department of Physiology, Kitasato University, School of Medicine, Kanagawa, Japan.
}

ronal properties and probing the altered mechanisms in different mutants. However, existing Drosophila primary embryonic cultures prepared from the whole embryo are highly heterogeneous, containing many other cell types in addition to neurons (Seecof and Unanue, 1968; Shields and Sang, 1970; Schneider and Blumenthal, 1978). Certain embryonic cell lines exhibiting morphology of neurons have been reported, although their developmental origins and physiological properties are not known (Cherbas et al., 1980). Therefore, it is desirable to establish a culture system of dissociated neurons from the nervous tissue of a postembryonic stage so that comparison can be made with previous in situ neurophysiological and biochemical studies. However, earlier attempts to culture tissue from Drosophila larvae or adults have attained little success (Sang, 1981).

We report here a primary culture of dissociated neurons of the central nervous system (CNS) of Drosophila third instar larvae, in which the CNS undergoes vigorous development (White and Kankel, 1978). The procedure was relatively simple, requiring only a few brains and/or ganglia for each experiment. The cultures contained mainly neurons and neuroblasts, which underwent division to yield differentiated neurons in vitro.

This culture system made the relatively small Droso- 
phila neurons more accessible and may be suitable for the analysis of neuronal properties in different mutants with a variety of experimental techniques. We found that this system can be used in physiological, biochemical, and pharmacological experiments to gain the base line information of Drosophila CNS neurons that is otherwise difficult to obtain. It has been suggested that acetylcholine (ACh) is a major neurotransmitter in the CNS of Drosophila (Hall and Greenspan, 1979). Therefore, the ability of the cultured neurons to synthesize and accumulate $\mathrm{ACh}$ was determined. In addition, the presence of functional ACh channels in the Drosophila CNS was indicated because $\mathrm{ACh}$-induced single-channel currents could be readily recorded from the dissociated cells in culture. Ionic mechanisms of Drosophila CNS neurons have not been reported. Intracellular recording from somata indicated the presence of $\mathrm{Ca}$ channels in these dissociated neurons. We further demonstrated that cultured Drosophila neurons were sensitive to veratridine, a specific $\mathrm{Na}$ channel activator (Catterall, 1980) and that the cell-lethal effect of veratridine could be inhibited by the specific Na channel blocker tetrodotoxin (TTX).

A temperature-sensitive paralytic mutant $n a p^{t s}$ (Wu et al., 1978), in which nerve conduction fails at $34^{\circ} \mathrm{C}$, was further studied by using this culture system. The effect of nap $p^{t s}$ mutation on neuronal growth was examined. To investigate the suggestion that nap ${ }^{t s}$ affects $\mathrm{Na}$ channels (Wu and Ganetzky, 1980), we examined the possibility that nap ${ }^{t s}$ neurons show altered reaction to veratridine. A preliminary account of part of this work has been reported previously (Wu et al., 1981).

\section{Materials and Methods}

Preparation of culture media. A revised Schneider medium (Schneider, 1964) from Grand Island Biological Co. (GIBCO; Grand Island, NY) was used in most experiments. In initial experiments, a medium (modified Drosophila medium) was constructed from a mixture of $27 \%$ L-15 (Leibovitz) medium (GIBCO) and 73\% of a saline whose salt composition was similar to that of Schneider medium (5.4 mM CaCl$, 21.4 \mathrm{mM} \mathrm{KCl}, 12.3 \mathrm{mM} \mathrm{MgCl}_{2}$, $36.0 \mathrm{mM} \mathrm{NaCl}, 4.8 \mathrm{mM} \mathrm{NaHCO}_{3}, 1.5 \mathrm{mM} \mathrm{KH}_{2} \mathrm{PO}_{4}, 11.1$ $\mathrm{mm}$ glucose, and $24.8 \mathrm{mM}$ Tris, $\mathrm{pH} 7.1$ ). The culture media were supplemented with heat-inactivated $\left(56^{\circ} \mathrm{C}\right.$, 30 min) fetal bovine serum (10\%), penicillin G (50 units/ $\mathrm{ml})$, and streptomycin sulfate $(50 \mu \mathrm{g} / \mathrm{ml})$, all obtained from GIBCO.

Preparation of cell culture. Mature third instar larvae of wild-type (Canton-S) or nap ${ }^{t s}$ (Wu et al., 1978) Drosophila melanogaster were used. Before dissection, larvae were surface-sterilized by brief immersion in $70 \%$ ethyl alcohol and then rinsed three times with sterile distilled water. The brain and ventral ganglion were dissected from larvae in tissue culture medium, and segmental nerves, imaginal discs, and other tissues were removed.

The procedure for obtaining dissociated cell suspensions from the brains and ganglia was similar to that described by Moscona (1961) for the avian primary dissociated cell culture. After rinsing, the brains and ganglia were first torn into small fragments in the culture medium with fine dissecting needles and then incubated for $1 \mathrm{hr}$ in a saline similar to Rinaldini's (Schneider and
Blumenthal, 1978) $\mathrm{Ca}^{2+}$ - and $\mathrm{Mg}^{2+}$-free solution (800 $\mathrm{mg}$ of $\mathrm{NaCl}, 20 \mathrm{mg}$ of $\mathrm{KCl}, 5 \mathrm{mg}$ of $\mathrm{NaH}_{2} \mathrm{PO}_{4} \cdot \mathrm{H}_{2} \mathrm{O}, 100 \mathrm{mg}$ of $\mathrm{NaHCO}_{3}$, and $100 \mathrm{mg}$ of glucose, in $100 \mathrm{ml}$ of distilled water) containing 0.1 to $0.5 \mathrm{mg} / \mathrm{ml}$ of collagenase (type I, Sigma Chemical Co., St. Louis, MO). The fragments were rinsed three times with culture medium supplemented with $10 \%$ fetal bovine serum and then dispersed into single cells in the same medium by repeatedly flushing through a siliconized glass pipette.

To obtain monolayer cultures, 80 to $200 \mu \mathrm{l}$ of cell suspension were added into a plastic Petri dish containing $1 \mathrm{ml}$ of culture medium or directly onto round glass coverslips (10 to $20 \mathrm{~mm}$ diameter) in dry Petri dishes to form minicultures confined by surface tension of medium. The coverslips and the Petri dishes were precoated with poly-L-lysine $\left(M_{\mathrm{r}} \sim 10,000\right.$; Sigma $)$. Cultures with densities ranging from 0.5 to $5 \times 10^{4}$ cells $/ \mathrm{cm}^{2}$ were incubated in air atmosphere at room temperature. To minimize the problem of evaporation, drops of additional culture medium in separation from the minicultures were added in the Petri dish, and the dish was covered and kept in a moist chamber. Dissociation of the brain and ganglion of a single larva yielded about $10^{5}$ single cells in suspension as determined with a microhemocytometer. Within $2 \mathrm{hr}$ cells in suspension adhered to the dish or cover glass. The fraction of all single cells in suspension that adhered and formed the monolayer culture was $20 \%$ or more.

Morphology of the cultured cells was studied with phase contrast or Nomarski optics. To conduct dye exclusion tests for cell viability, cultured neurons were stained with $0.04 \%$ erythrosine B for 5 min according to the procedure previously described (Phillips and Terryberry, 1957; Phillips and Andrews, 1959), with the omission of using trypsin to detach the cells from the culture dish. The cell morphology remained intact after staining and subsequent rinsing in Drosophila physiological saline (see below). The differential staining of nonviable cells could be readily scored with bright-field optics.

For pharmacological experiments, stock solutions of purified veratridine (Sigma; $3 \mathrm{~mm}$ in Schneider medium) or TTX (Calbiochem; $0.5 \mu \mathrm{M}$ to $5 \mathrm{mM}$ in distilled water) were added to culture medium to achieve the concentrations specified in each experiment. These toxins were of the same grade as those used by previous investigators (West and Catterall, 1979). In experiments of Figures 5, 9 , and 10 , cell counts included only neurons with neurites longer than $5 \mu \mathrm{m}$, which could be reliably resolved. To reduce the possible complications introduced by interactions between viable and nonviable cells, cells in aggregates were excluded from the scoring. In each experiment, cells in a fixed area $\left(3.3 \mathrm{~mm}^{2}\right)$ demarcated by grids on the culture dish were scored over a time span of 7 days. To determine the rate of neurite growth, random samples of neurons (with neurite $>5 \mu \mathrm{m}$ ) in cultures of various ages were photographed and the length of the longest primary process of each cell was determined on photographs. Approximately equal numbers of type II and type III cells were included in each sample. Procedures in this study were performed at room temperature $\left(21\right.$ to $23^{\circ} \mathrm{C}$ ) unless stated otherwise.

Electrophysiological methods. Intracellular records 
were obtained from cells plated on the cover glass. After completion of dissociation, plating, and incubation, the cover glass with cells was transferred to a glass-bottomed chamber containing about $1 \mathrm{ml}$ of a Drosophila physiological saline (Jan and Jan, 1976) of the following composition: $128.0 \mathrm{mM} \mathrm{NaCl}, 2.0 \mathrm{mM} \mathrm{KCl}, 4.0 \mathrm{mM} \mathrm{MgCl}_{2}$, $1.8 \mathrm{mM} \mathrm{CaCl}_{2}, 35.5 \mathrm{mM}$ sucrose, and 5.0 $\mathrm{mm}$ HEPES (pH 7.1). $\mathrm{SrCl}_{2}$ or $\mathrm{BaCl}_{2}$ (5 to $10 \mathrm{mM}$ ) was sometimes added to the saline to produce $\mathrm{Sr}$ or $\mathrm{Ba}$ action potentials. No adjustment was made for the small osmolarity change introduced by the additional ions. The cells on the cover glass were visualized with an "upright" compound microscope equipped with Nomarski optics ( $\times 40$ water immersion objective and $\times 10$ ocular lens; Carl Zeiss, Inc., Thornwood, NY). The microscope and the micromanipulator (E. Licht Co., Denver, CO) for positioning the microelectrode were mounted on a pneumatic anti-vibration table (Micro-g; Technical Manufacturing Corp., Woburn, MA). Finc glass microclectrodes were pulled by a Brown-Flaming type puller (Sutter Instrument Co., San Francisco, CA) and had a resistance of 50 to 100 megohms when filled with $2 \mathrm{M} \mathrm{KCl}$. The recording electrode was also used to pass polarizing current $(<0.1 \mathrm{nA})$. 'The potential drop due to the microelectrode resistance was balanced out by a bridge circuit in the high inputimpedence electrometer (M-707; W-P Instruments, Inc., New Haven, CT). Signals were then displayed on a storage oscilloscope and photographed.

Extracellular patch clamp recordings were performed in a glass-bottomed chamber containing physiological saline. The patch clamp circuit and recording methods were the same as described by Hamill et al. (1981). The experimental setup was similar to that used in the intracellular recordings described above. The major differences included the use of a long working distance objective (UD 40, Carl Zeiss) and a hydraulic microdrive (Narishige, Tokyo, Japan) to manipulate the patch micropipette. The micropipettes were fire polished to achieve an opening of $1 \mu \mathrm{m}$ and filled with the physiological saline with (or without) the addition of $100 \mathrm{nM}$ ACh. The pipette resistance was 5 to 10 megohms. The resistance increased up to 10 gigohms when the opening was sealed by the cell membrane. The preparation was cooled to $15^{\circ} \mathrm{C}$ by a Peltier junction microscope stage to slow down the ion channel kinetics. Signals were filtered at $1 \mathrm{kHz}$.

Measurements of synthesis and accumulation of $\left[{ }^{3} \mathrm{H}\right]$ $A C h$. Dissociated cells growing on a cover glass $(9 \mathrm{~mm}$ diameter) were incubated at $21^{\circ} \mathrm{C}$ for $1 \mathrm{hr}$ in $50 \mu \mathrm{l}$ of medium containing $1.3 \mu \mathrm{M}\left[{ }^{3} \mathrm{H}\right]$ choline $(77 \mathrm{Ci} / \mathrm{mmol}$, Amershan/Searle, Arlington Heights, IL). After incubation, the cultures were rinsed three times (for $30 \mathrm{sec}$ each time) in culture medium. $\left[{ }^{3} \mathrm{H}\right] \mathrm{ACh}$ and other metabolites accumulated in cultured cells were then extracted and subjected to high-voltage electrophoresis and scintillation counting according to the procedure previously described by Hildebrand et al. (1971) and Auerbach and Barker (1981). The same procedure has been used in a study of $\left[{ }^{3} \mathrm{H}\right]$ choline metabolism in the intact CNS of Drosophila larvae (Wu et al., 1983).

\section{Results}

Primary dissociated cell culture. There has been no previous report on cell culture of postembryonic neurons of Drosophila. To examine the possibility of establishing a culture system of Drosophila CNS neurons, the brain and ventral ganglion of third instar larvae were dissociated and grown in culture medium.

Immediately after completion of plating, more than $30 \%$ of the dissociated cells were found to have axon-like processes with growth cones. After $24 \mathrm{hr}$, a large proportion $(>60 \%)$ of cells exhibited one or more processes with extensive branching (Fig. 1) and, apparently, eventually formed contacts with other cells (Fig. 2). Cultures have been routinely maintained for more than a week (Fig. 2). Some cultures survived for up to 40 days without replating. We found that the modified Drosophila medium and Schneider medium gave qualitatively similar results.

Since the cultures contained various cell types that are present in the larval CNS, their morphology and growth in culture were characterized. Immediately after plating, cells of different sizes and morphology were observed and could be conveniently divided into three categories according to size. Figure 3 shows the range of variation encountered in cultures. Type I consisted of large $(>8$ $\mu \mathrm{m})$ neuroblast-like cells which comprised $<10 \%$ of the total population and were usually accompanied by smaller cells (Fig. 3, $a$ to $c$ ). Type II cells comprised the largest population ( 30 to $40 \%$ ) in the culture. They were small, relatively uniform in size (2 to $3 \mu \mathrm{m})$, and frequently had processes $(<20 \mu \mathrm{m})$ (Fig. $3, d$ to $f)$. The type III cells (20 to $30 \%$ ) had an oval or spindle-shaped cell body of intermediate size ( 4 to $10 \mu \mathrm{m}$ ), which frequently exhibited thick and short axon-like processes (Fig. 3, g to $i$ ). The remaining (20 to $30 \%$ ) were mostly spherical cells of varying sizes, which did not have processes (Figs. $3, g$ and $h$, and $4, c$ and $e$, arrows). Surprisingly, cells such as fibroblasts or glia that did not fall into the above categories were rarely encountered $(<1 \%)$ in cultures.

Dynamics of different cell populations. To study the developmental relations among the cell types, cultures were subject to time lapse observations. Many type I cells were found to undergo asymmetric divisions typical of neuroblasts (Nordlander and Edwards, 1969; White and Kankel, 1978), giving rise to small accompanying cells which usually initiated neurite outgrowth within 24 hr (Fig. 4) and assumed morphology resembling type II cells. After 1 to 2 days in culture, they had complex morphology similar to that shown in Figs. 1, $c$ and $d$, and $2, a$ and $c$. Freshly dissociated cells have also been continuously observed with Nomarski optics during patch clamp recordings (see "Materials and Methods"). On many occasions, cell divisions in progress were sighted. Morphological changes of type I cells resulting from cytokinesis could be detected over a brief period $(<10$ min). Type III cells differentiated into either monopolar or multipolar cells (for example, see Figs. 1, $a$ and $b$, and $2 b$, arrows), which sent out thicker neurites with more profuse branching patterns than those of type II cells. The possible developmental relationship between type I 

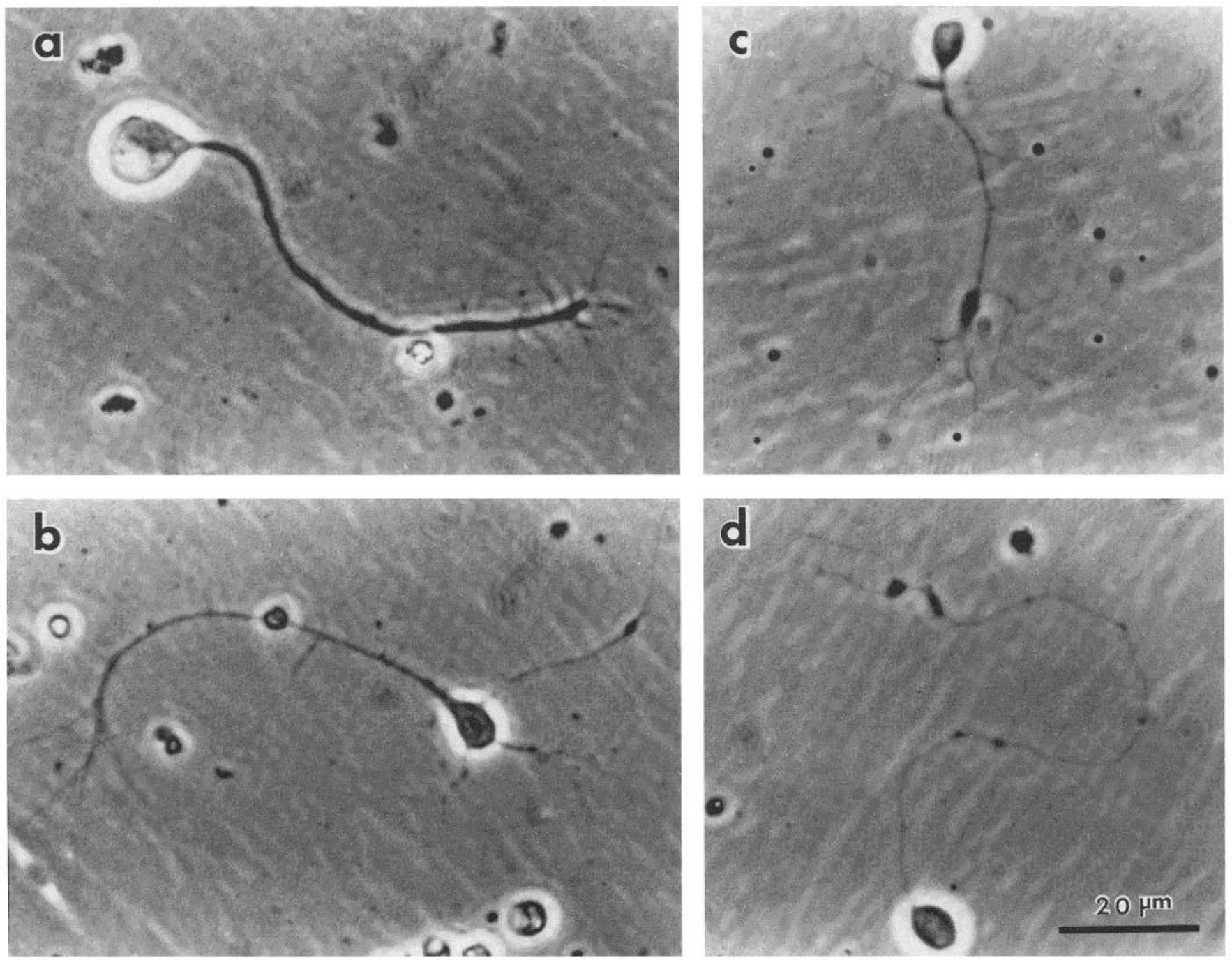

Figure 1. Single neurons dissociated from the CNS of mature third instar larvae. Twenty-four-hour culture. Phase contrast.

and type III cells has not been carefully studied. Time lapse observations indicated that neuritic contacts formed among neurons of either type II or III or between these two types (Fig. 2b). Whether functional synapses were established at these contacts remains to be examined.

The origin of spherical cells was revealed by time lapse studies of survival of the various cell types in culture. Degenerating neuroblasts and neurons (type II and III) first became spherical cells of different sizes (Figs. 3, $g$ and $h$, and 4, $c$ and $e$,arrows) and finally detached from the culture dish in 1 to 2 days. Erythrosine B $(0.04 \%)$ was employed to test cell viability because it differentially stains nonviable cells (Phillip and Terryberry, 1957). In cultures of different ages ( 1 to 7 days), we found that the majority of spherical cells were stained, whereas neurons with neurites remained unstained. Despite the fact that spherical cells detached from the culture dish within 2 days, the relative density of the spherical cells was rather constant (20 to $30 \%$ ) in cultures of different ages. This is the expected result if the culture has random cell death at a constant rate.
The change in densities of putative neurons (type II and III cells with neurites $>5 \mu \mathrm{m}$ ) with increasing culture age was quantified in time lapse studies. Figure 5 shows the relative density of these cells at various ages as fraction of the density at initiation of the culture. The density of neurons declined to about $50 \%$ in 7 days. ${ }^{4}$ The density of viable type I cells decreased with age and they were less frequently observed in cultures older than 3 days. The average neurite length was found to increase with culture age (Fig. 5). Although there was a large variation in the neurite length of neurons in the same culture, it can be seen that the mean neurite length increased rapidly in the first 2 days and reached a steady state thereafter. ${ }^{5}$ Therefore, cultures entering a steady state (at age of 3 or 4 days) may be employed in morphological studies of alterations induced by different factors such as pharmacological agents (see below).

\footnotetext{
${ }^{4}$ No significant change was found in the relative ratio of type II to type III cells in cultures of different ages.

${ }^{5}$ No significant difference between the neurite length of type II and type III cells was observed.
} 

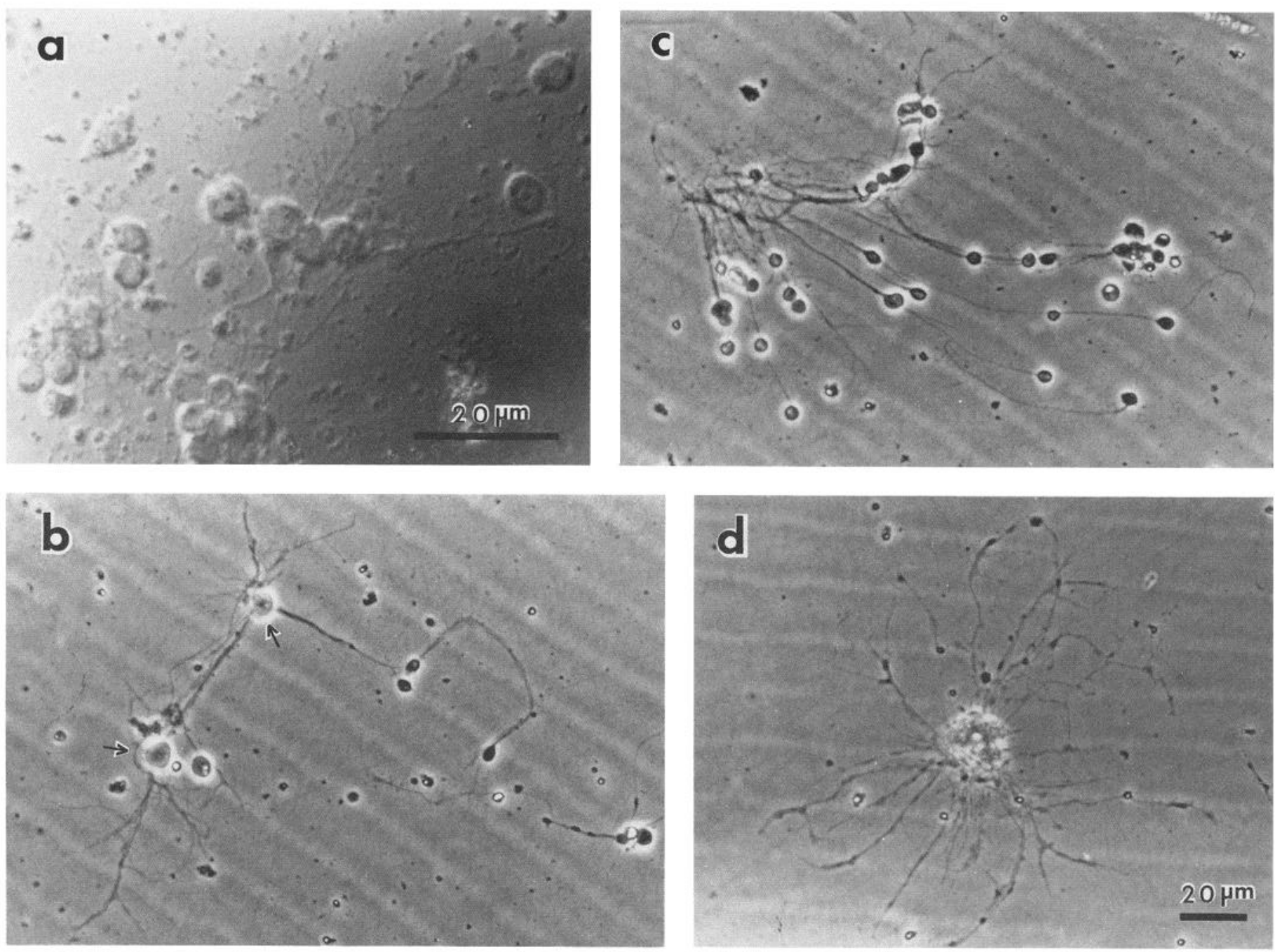

Figure 2. Formation of networks of neurites among cultured neurons. $a$, Three-day culture; $b$ and $c, 9$-day cultures; $d$, neuronal aggregate, 11-day culture. Arrows in $b$ indicate the somata of large multipolar neurons. Nomarski optics $(a)$ and phase contrast $(b, c$, and $d$, same magnification).
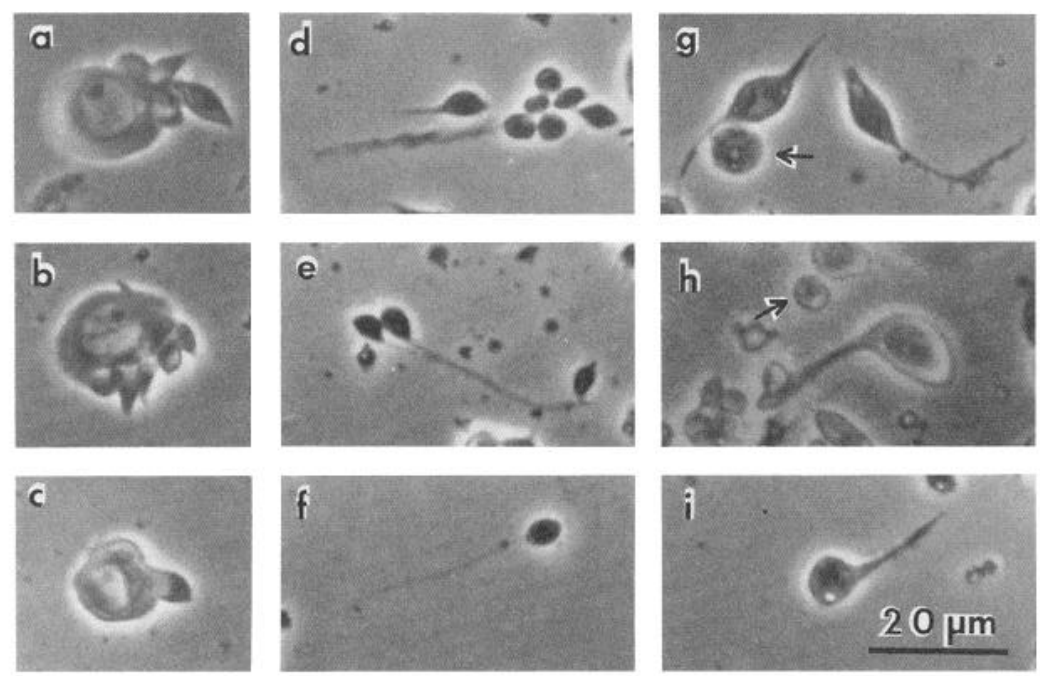

Figure 3. Examples of type I ( $a, b$, and $c$ ), type II ( $d, e$, and $f)$, and type III ( $g$, $h$, and $i$ ) cells in cultures immediately after completion of plating. Spherical cells are indicated by arrows. Phase contrast. 

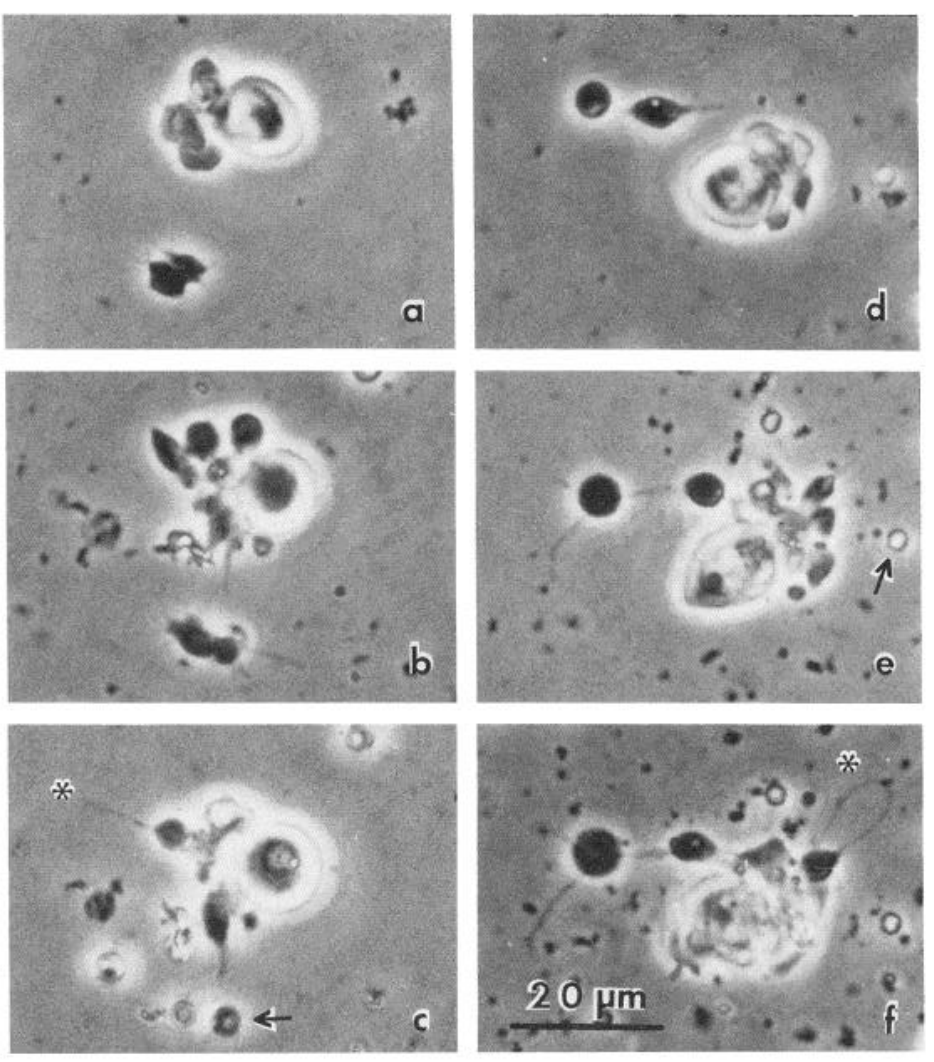

Figure 4. Time lapse observations of neuroblasts undergoing asymmetric division. $a$ to $c$, A series of photographs of a neuroblast taken at 1,21 , and $46 \mathrm{hr}$, respectively, after initiation of culture. $d$ to $f$, Another series of a different neuroblast at 2, 12 , and $28 \mathrm{hr}$, respectively. The number of daughter cells increased from 4 in $a$ to 8 in $b$ and from 4 in $d$ to 7 in $e$ (some were not in focus). Note also the initiation of neurite outgrowth ( $c$ and $f$, asterisks). Arrows indicate spherical cells. Phase contrast.

The identification of non-neuronal cells in the culture can not be absolutely certain until other specific tests are performed. However, viable cells which did not fall into the categories described above and which showed distinct fibroblast or glial morphology (Shields and Sang, 1970; Strausfeld, 1976; Sang, 1981) remained rare $(<1 \%)$ throughout the culture life. The above results suggest that the great majority of viable cells in this culture system are neurons by morphological criteria. Dissociated neurons obtained from several neurological mutants (Siddiqi and Benzer, 1976; Jan et al., 1977; Wu et al., 1978) have been grown in culture and have shown similar results. In order to study the primary defects in these mutants, the following electrophysiological, biochemical, and pharmacological experiments were performed to gain basic information about CNS neurons of Drosophila.

ACh accumulation and ACh-induced single-channel currents. ACh has been indicated to be a major transmitter in the CNS of Drosophila (Hall and Greenspan, 1979). High efficiency of ACh synthesis from choline has been shown in intact larval and adult CNS of Drosophila, whereas no synthesis has been found in other tissues
(Wu et al., 1983). Thus we examined whether the dissociated neurons retained the ability to synthesize and accumulate ACh.

After incubation in $\left[{ }^{3} \mathrm{H}\right]$ choline for $1 \mathrm{hr}$, the dissociated cells in 24-hr cultures synthesized and accumulated $\left[{ }^{3} \mathrm{H}\right] \mathrm{ACh}$ with an efficiency comparable to that of the intact larval CNS (cf. Wu et al., 1983). Figure 6 compares the results obtained from the intact CNS of two larvae and from dissociated cells from the same amount of nerve tissue. The results suggest the presence of a large population of differentiated cholinergic neurons in the culture as in situ.

High density of putative $\mathrm{ACh}$ receptors has been demonstrated in the adult CNS of Drosophila (Hall and Teng, 1975; Dudai, 1977; Schmidt-Nielsen et al., 1977). However, no physiological recordings of ACh-induced responses have been reported in Drosophila. Dissociated neurons in culture provide clean membrane surfaces for patch clamp recordings of single-channel currents. Larger cells in this culture system reached a dimension $(\leq 10 \mu \mathrm{m})$ suitable for the extracellular patch recording (Tanouye and $\mathrm{Wu}, 1982$ ). Without application of suction, high seal resistance (up to 10 gigohms) could occur spontaneously when the electrode tip touched the cell membrane.

In 4-hr cultures, single-channel currents could be recorded from large type III cells with a patch electrode filled with saline containing $100 \mathrm{nM}$ ACh (Fig. 7), but not with an electrode without ACh. These currents persisted when the electrode contained $3 \mu \mathrm{M}$ TTX and 25 mM tetraethylammonium (TEA) in addition to ACh. The potential inside the patch electrode was held at various levels (from -80 to $40 \mathrm{mV}$ ), but the resting membrane potential was not known. In 16 different single channels recorded, the mean channel open time was from about 2 to $3.5 \mathrm{msec}$. The current amplitude was about 0.7 to 2 $\mathrm{pA}$ in outward direction when the membrane potential of the patches was held at $80 \mathrm{mV}$ positive to the resting potential, and it became about 0.4 to $1 \mathrm{pA}$ in inward direction when the membrane was held at $40 \mathrm{mV}$ negative to the resting potential. The voltage dependence of the single channel currents was roughly linear, giving a single channel conductance of approximately 9 to $25 \mathrm{pS}$ in the voltage range tested. A detailed report of the properties of these single channel currents is in preparation.

Electrical excitability. Intracellular recording of Drosophila neurons in situ is technically difficult. This culture system made the relatively small Drosophila neurons individually visible and more accessible to intracellular recording. Thus the excitability of the somata of cultured neurons was examined. Neuroblasts and larger type III cells $(>7 \mu \mathrm{m})$ in 8 - to 12 -hr cultures were penetrated with microelectrodes. At this culture age, the observed amplitude of the resting membrane potential was usually $25 \mathrm{mV}$ or less $(n>20)$ and no action potential could be evoked during injection of depolarizing currents or following strong $(-80 \mathrm{mV})$ hyperpolarizing pulses (anode break excitation).

In many excitable tissues $\mathrm{Na}$ channels are not present and inward currents are gated by $\mathrm{Ca}$ channels. In a variety of such tissues (Hagiwara and Byerly, 1981) 


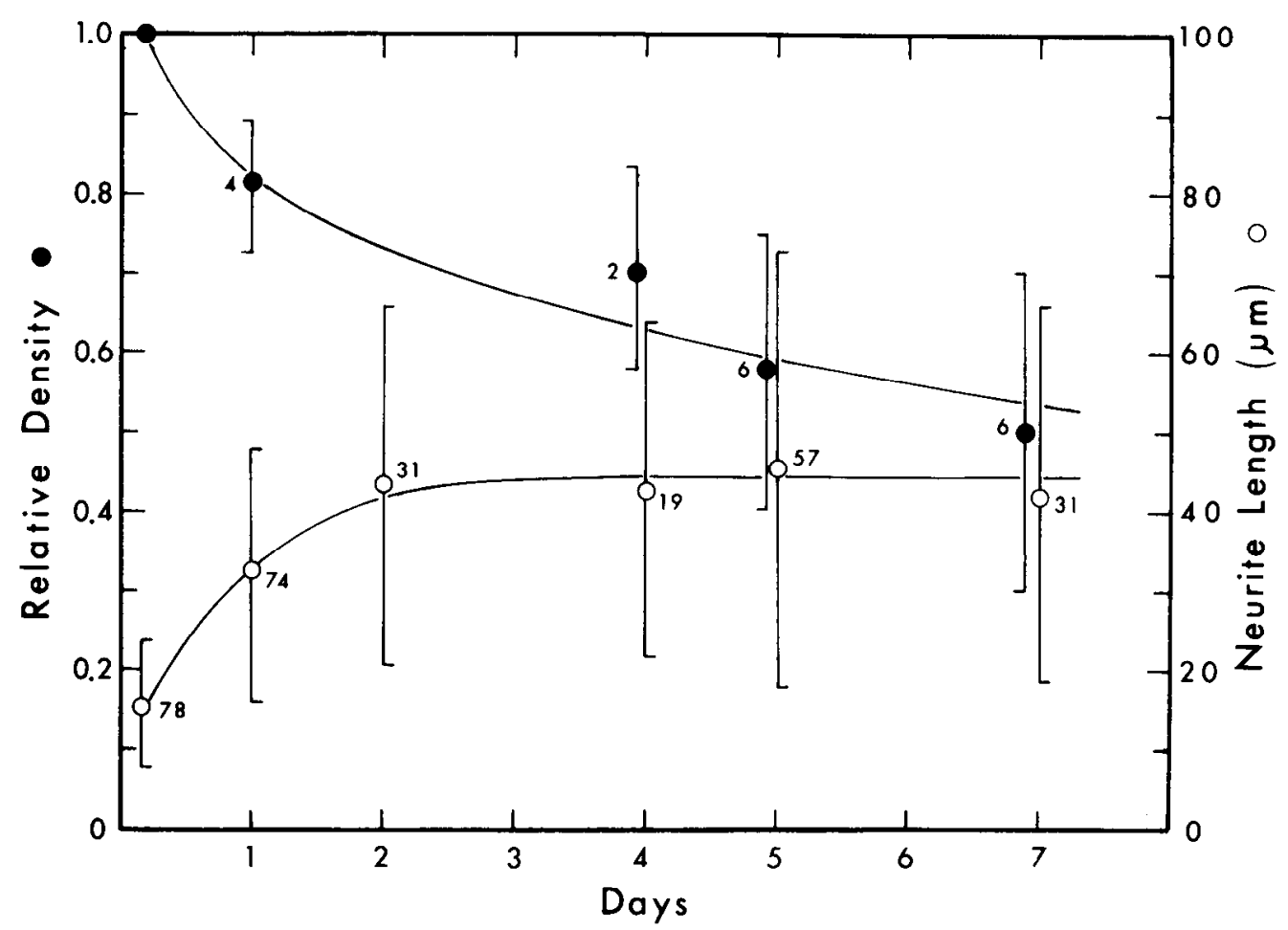

Figure 5. Density of viable neurons and length of neurites as functions of age. Solid circles represent the cell density normalized to the initial value as determined in the number of cultures indicated. Open circles represent the average of the neurite length from the number of neurons indicated. Error bars represent SD.

including Drosophila larval muscles (Suzuki and Kano, 1977), regenerative $\mathrm{Ca}$ action potentials are prevented by strong outward $\mathrm{K}$ rectification currents. However, depolarization supported by inward currents through $\mathrm{Ca}$ channels can develop into action potentials when $\mathrm{K}$ rectification is reduced by TEA. The presence of $\mathrm{Ca}$ channels can be more conveniently demonstrated by adding $\mathrm{Sr}^{2+}$ or $\mathrm{Ba}^{2+}$ to the bathing solution because these cations flow through $\mathrm{Ca}$ channels more effectively than $\mathrm{Ca}^{2+}$ and because they also interfere with the $\mathrm{K}$ rectification currents (Hagiwara and Byerly, 1981).

To examine whether $\mathrm{Ca}$ channels were present in neurons at this stage ( 8 to $12 \mathrm{hr}$ ), we added $\mathrm{Sr}^{2+}$ or $\mathrm{Ba}^{2+}$ (5 to $10 \mathrm{~mm}$ ) to the saline. Large, overshooting, regenerative membrane potentials could be elicited by current injection in type III cells with or without neurites. Figure 8 shows examples of these relatively prolonged ( $>10$ msec) potentials recorded in the presence of $\mathrm{Sr}^{2+}$.

Sensitivity to neurotoxins specific to $\mathrm{Na}$ channels. The above result suggests the appearance of $\mathrm{Ca}$ channels in dissociated neurons cultured for 8 to $12 \mathrm{hr}$ but fails to demonstrate the presence of voltage-sensitive $\mathrm{Na}$ channels in these cells. Because of the small size (generally 2 to $10 \mu \mathrm{m}$ ) of dissociated Drosophila neurons, intracellular recording is not an effective means to survey the properties of various cell types in cultures of different ages. Neurotoxins highly specific to voltage-sensitive Na channels are available and their effects on cultured neurons can be quantified. Veratridine depolarizes the nerve membrane by blocking $\mathrm{Na}$ inactivation and by shifting $\mathrm{Na}$ activation to more negative potential, leading to lethality of neurons (West and Catterall, 1979). The effect of veratridine is noncompetitively inhibited by the Na channel blocker TTX (Catterall, 1980).

Neurons in 4-day cultures were subjected to veratridine treatment. At this stage the cultured neurons appeared to reach maturity as the neurites stopped further lengthening (Fig. 5). Single cells in each culture confined in a fixed area were scored (see "Materials and Methods") immediately before the application of veratridine and on successive days. Veratridine $(500 \mu \mathrm{M})$ in medium reduced the density of neurons with neurites $(>5 \mu \mathrm{m})$ after 1 day to $27 \%$ and after 3 days to $11 \%$ of the pretreatment value (cf. the data point of $0 \mathrm{nM}$ TTX and $500 \mu \mathrm{M}$ veratridine in Fig. 9). It was noted that the population of spherical cells correspondingly increased and that both type II and type III cells were sensitive to veratridine. In contrast, $77 \%$ of neurons remained in the control cultures (without drug) after 1 day and $71 \%$ survived after 3 days (Fig. 9).

Figure 9 also shows the density of neurons (as fraction of the pretreatment density) 1 day after veratridine treatment when TTX was applied 30 min prior to veratridine. The dose response demonstrated that the lethal effect of veratridine was inhibited by high concentration of TTX. It also provided strong evidence that the lethal effect of veratridine was mediated by voltage-dependent $\mathrm{Na}$ channels present in cultured neurons.

Neuronal growth and sensitivity to veratridine in nap ${ }^{\text {ts }}$ mutant. The larval nerve axons in the mutant $n a p^{t s}$ fail to conduct action potentials and are more sensitive than normal to TTX even at $21^{\circ} \mathrm{C}$, a temperature at which $n a p^{t s}$ individuals behave normally ( $\mathrm{Wu}$ and Ganetzky, 1980). This raises the possibility that neuronal growth may also be affected in this mutant. A related question 

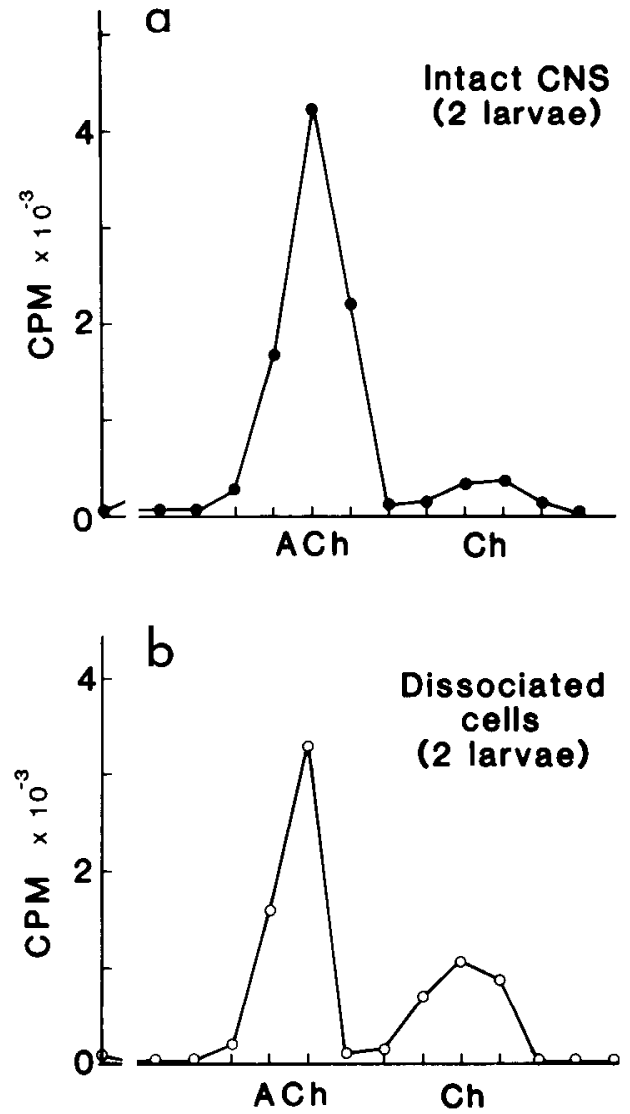

Figure 6. Synthesis and accumulation of $\left[{ }^{3} \mathrm{H}\right] \mathrm{ACh}$ from $\left[{ }^{3} \mathrm{H}\right]$ choline in Drosophila neurons. Electropherograms with the positions of $\mathrm{ACh}$ and choline $(\mathrm{Ch})$ standards indicated. $a$, In situ. Intact brains and ganglia from two larvae. $b$, In 24-hr culture. Dissociated cells from two larvae. Note that comparable amounts of synthesis and accumulation of $\left[{ }^{3} \mathrm{H}\right] \mathrm{ACh}$ for cells in $a$ and $b$.

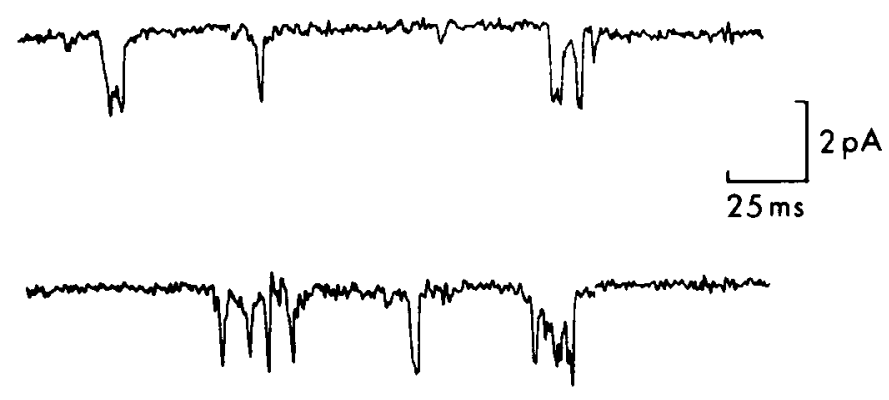

Figure 7. ACh-activated single-channel currents from cultured Drosophila neurons. Type III cell, $15^{\circ} \mathrm{C}$. The membrane potential of the patch was held at $80 \mathrm{mV}$ positive to the resting potential. Downward deflections indicate outward currents.

concerns the possible effect of TTX on the growth of dissociated Drosophila neurons. To answer these questions, cultures of nap $p^{t s}$ neurons and cultures of normal neurons treated with TTX $(1 \mu \mathrm{M})$ were examined and the results were compared with the normal growth characterized in Figure 5. The survival rate and neurite length of neurons in neither $n a p^{t s}$ cultures nor TTX-treated cultures differed significantly from those of control cultures (Fig. 5). The relative densities of type II and type
III cells in these cultures were not notably altered. Raising $n a p^{t s}$ cultures at $34^{\circ} \mathrm{C}$ (a restrictive temperature) did not change the growth pattern of neurons, either. The same was true for cultures of normal neurons. Thus, at the present level of quantification, we did not detect a change in neuronal growth as a consequence of $n a p^{t s}$ mutation or TTX treatment.

The action potential in nap $p^{t s}$ larvae exhibits an abnormally prolonged refractory period (Wu and Ganetzky, 1980). Since the refractory period is in part determined by the $\mathrm{Na}$ inactivation process (Hodgkin and Huxley, 1952), it is of interest to investigate the sensitivity of $n a p^{t s}$ neurons to veratridine, which blocks $\mathrm{Na}$ inactivation (Catterall, 1980).

Utilizing this culture system, we compared the survival of $n a p^{t s}$ and normal neurons 1 day after the application of veratridine at different concentrations up to $500 \mu \mathrm{M}$ (Fig. 10). It is evident that, at $21^{\circ} \mathrm{C}$, nap $^{t s}$ neurons showed a drastically reduced sensitivity to the lethal effect of veratridine. The question remains whether the decreased sensitivity of $n a p^{t s}$ neurons is a consequence of altered binding properties of $\mathrm{Na}$ channels to veratridine or simply a lack of $\mathrm{Na}$ channels in the neuronal membrane. The following observations indicate that lack of $\mathrm{Na}$ channels probably is not an explanation for the observed reduction in veratridine sensitivity in $n a p^{t s}$ neurons. Prolonged treatment with veratridine caused more pronounced lethality of neurons in $n a p^{t s}$ cultures. At the end of a 3-day period, the density of nap ${ }^{t s}$ neurons descreased to $31.4 \pm 13.8 \%$ (mean $\pm \mathrm{SD}, n=9$ cultures) when treated with $500 \mu \mathrm{M}$ veratridine and to $60.0 \pm 18.6(n=$ 6 ) in control cultures without veratridine treatment. (The corresponding values for the normal neurons were $10.6 \pm 8.0 \%(n=8)$ and $71.8 \pm 20.7 \%(n=6)$, as shown
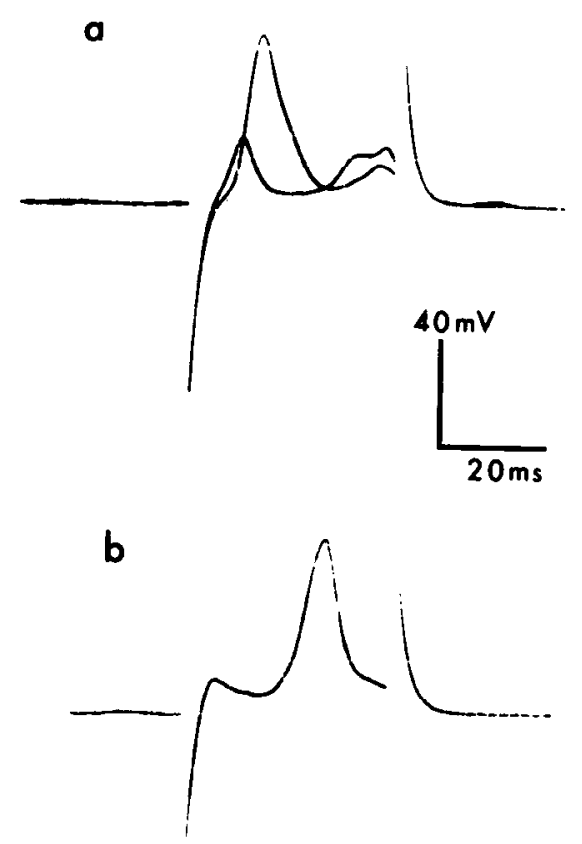

Figure 8. Typical regenerative membrane potentials recorded intracellularly from dissociated cells cultured for 8 to $10 \mathrm{hr}$. $a$, Action potential initiated by depolarizing current injection. The saline contained $10 \mathrm{mM} \mathrm{SrCl}_{2}, b, \mathrm{~A}$ record from a different cell. Same conditions as in $a$. 


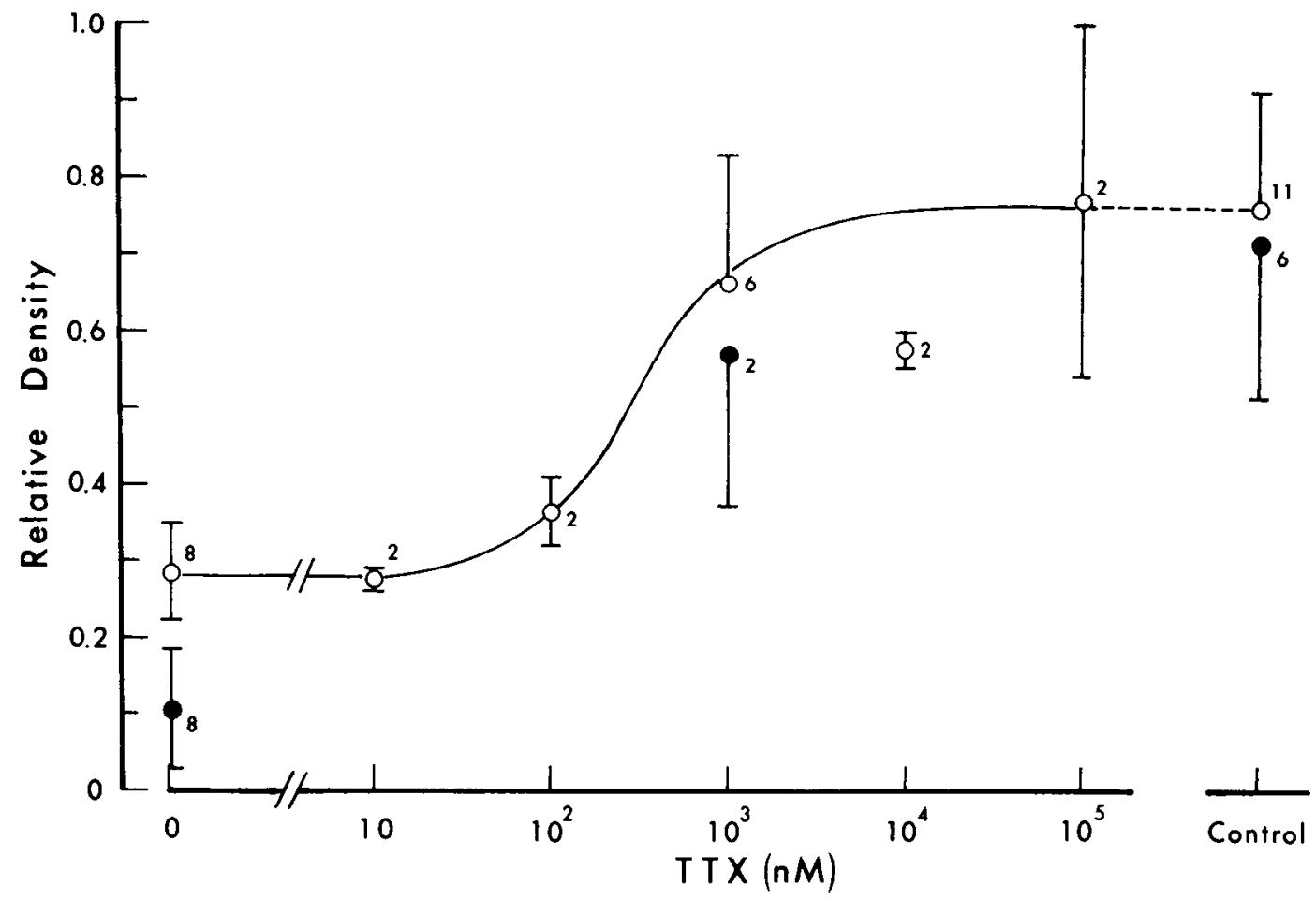

Figure 9. Inhibition of veratridine-induced cell lethality by TTX. Each point represents the fraction of neurons remaining 1 day (open circles) and 3 days (solid circles) after the application of $500 \mu \mathrm{M}$ veratridine plus TTX at different concentrations. No drug was applied in control cultures. The number of cultures for each determination and SD (or range when $n=2$ ) are indicated.

in Figure 5.) Furthermore, veratridine at $1 \mathrm{mM}$ concentration reduced the density of nap ${ }^{t s}$ neurons to $34.3 \pm$ $11.0 \%(n=3)$ in 1 day and to $19.0 \pm 10.0 \%(n=3)$ in 3 days. ${ }^{6}$ The above results mean that the density of $\mathrm{Na}$ channels in $n a p^{t s}$ neuronal membrane was high enough to support sufficient steady $\mathrm{Na}^{+}$influx and depolarization, resulting in neuronal death, even though these lethal effects were triggered at higher veratridine concentration.

\section{Discussion}

Primary dissociated cell culture. In the present study, we have established the primary culture of dissociated neurons from the Drosophila CNS. This system was used to study the properties of CNS neurons of the normal and mutant Drosophila. The dissociated neurons showed vigorous growth in culture. 'This is presumably due to the fact that the mature larval CNS of holometabolous insects (Nordlander and Edwards, 1969; White and Kankel, 1978) undergoes rapid cell proliferation and growth before entering metamorphosis. In vivo autoradiographic analysis based on $\left[{ }^{3} \mathrm{H}\right]$ thymidine uptake has shown that large neuroblasts in the larval CNS generally go through a series of asymmetric divisions before and during pupation to give rise to smaller ganglion mother cells, which further divide to yield ganglion cells (Nordlander and Edwards, 1969; White and Kankel, 1978). Consequently, the larval primary cultures may include neurons of dif-

\footnotetext{
${ }^{6}$ The current general shortage of veratridine in the world market prohibited extensive experimentation involving the use of high concentration veratridine.
}

ferent developmental stages, which undergo further differentiation or regeneration in vitro. Neuroblasts engaging in asymmetric divisions have been frequently encountered at early stages of the culture (Fig. 4), similar to the previous report on embryonic cell cultures (Seecof et al., 1973). The present cell culture system permits continuous observation of neurons accessible to experimental manipulations and thus provides a complementary approach to previous in vivo studies of postembryonic development of the nervous system.

Neurons in this culture system are individually visible and suitable for studies at the single-cell level by established immunological, pharmacological, and neurophysiological techniques. Besides characteristic neurite outgrowth and contacts, we also observed in these cells unimpaired synthesis and accumulation of ACh (Fig. 6) as well as functional ACh channels (Fig. 7). The presence of the membrane channels responsible for regenerative action potentials was also indicated (Figs. 8 and 9).

Preliminary studies showed that a number of monoclonal antibodies raised against the adult Drosophila CNS (Fujita et al., 1981) cross-react with larval neurons in culture. We have tested several of these antibodies and they selectively stained subcellular regions or specific types of neurons in culture, suggesting the presence of adult neuronal antigens in different cultured neurons (Fujita et al., 1982). For further experiments that require a homogeneous neuronal population, the possibilities of immunofluorescence-activated cell sorting by flow cytometry or elimination of different cell types by immunocytotoxicity can be examined.

An interesting feature of the present system is that 


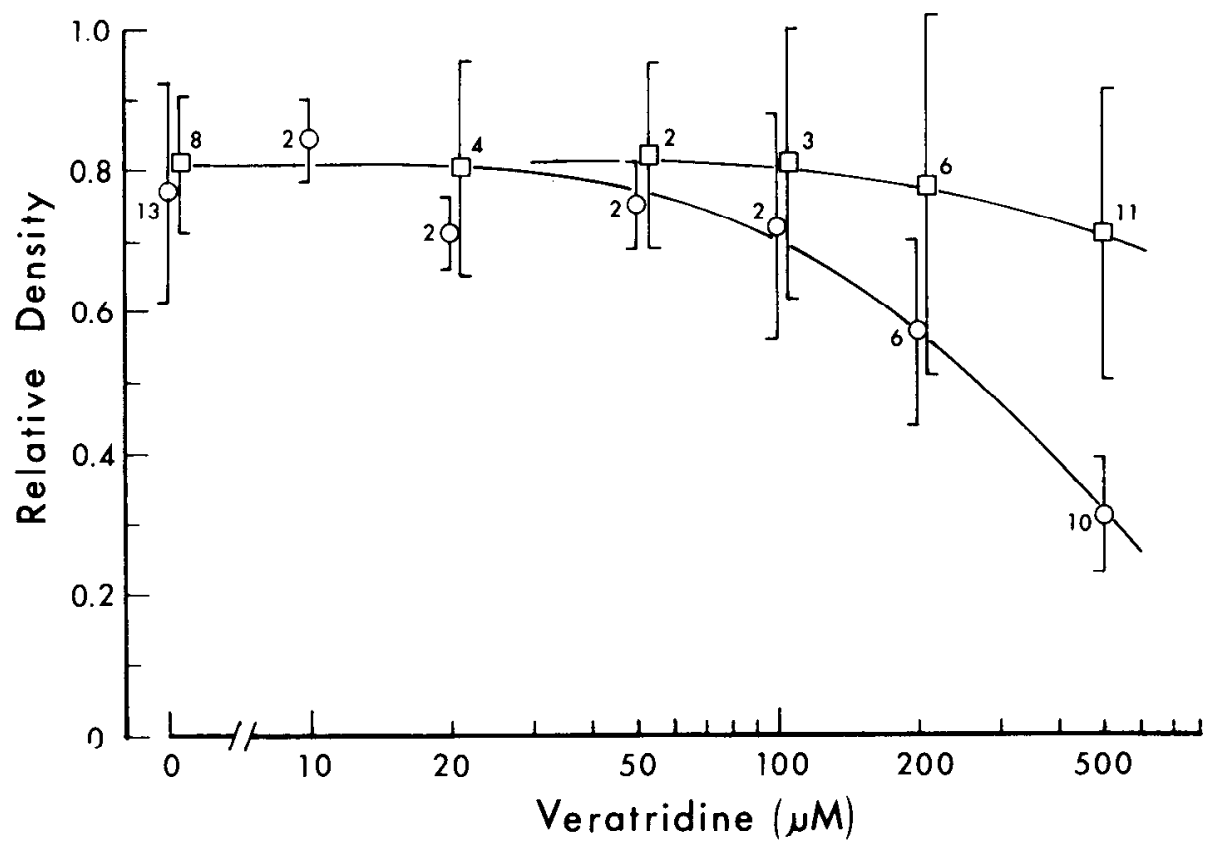

Figure 10. Effect of veratridine concentration on the survival of normal (circles) and nap $^{\text {ts }}$ (squares) neurons. The fraction of cells remaining 1 day after veratridine application was determined from the number of cultures indicated. Error bars represent SD (or range when $n=2$ ). The survival rate of $n a p^{t s}$ neurons at $500 \mu \mathrm{M}$ veratridine is significantly higher than that of normal neurons $(p<0.0001, d f=19)$.

neuronal cultures that appear to be relatively free from glial cells can be obtained from a few larval brains by using a simple dissociation procedure. Cells with distinct glial morphology (Strausfeld, 1976; Sang, 1981) were occasionally observed in cultures with either phase conrast optics or indirect immunofluorescence of monoclonal antibodies against the adult CNS (Fujita et al., 1981). However, among several thousand cells examined, the frequency of occurrence of cells which had clearly non-neuronal morphology was less than $1 \%$ in cultures of different ages. The apparently low density of glia in the cultures is probably not derived from a poor survival rate of glial cells in culture. Rather, the relatively low number of glia present in the insect CNS is a more likely explanation. In the brain of the adult fly Musca, somata of glia are only sparely distributed, in contrast to the dense packing of neuron somata (Strausfeld, 1976).

Physiological recordings. It was demonstrated that type I and type III cells were suitable for intracellular microelectrode and extracellular patch electrode recording. So far only neurons in relatively short-term (4 to $12 \mathrm{hr}$ ) cultures have been studied electrophysiologically. Singlechannel currents induced by ACh as well as regenerative action potentials were detected. The detection of functional ACh channels in these CNS neurons complements the previous biochemical evidence (Dudai, 1977; Schmidt-Nielsen et al., 1977; Wu et al., 1983) for the role of ACh as a neurotransmitter in the CNS of Drosophila. Because of the abundance of $\mathrm{ACh}$ receptors in the CNS of Drosophila (Dudai, 1977; Schmidt-Nielsen et al., 1977) as well as in other insects (Sattelle et al., 1980), further investigation into the properties and developmental sequence of the ACh channels in these cultured neurons is warranted.
In the presence of $\mathrm{Sr}^{2+}$ or $\mathrm{Ba}^{2+}$, the appearance of action potentials in dissociated neurons in 8 - to 12 -hr cultures is most likely associated with Ca channels. It is consistent with the earlier findings that, after an early developmental stage, $\mathrm{Ca}$ action potentials which are revealed or enhanced by $\mathrm{Ba}^{2+}$ or TEA can be recorded in embryonic neurons (Spitzer, 1979; Goodman and Spitzer, 1981). $\mathrm{Sr}^{2+}$ and $\mathrm{Ba}^{2+}$ are also effective in revealing $\mathrm{Ca}$ channel-dependent action potentials in mature excitable cells (Suzuki and Kano, 1977; Hagiwara and Byerly, 1981). However, our experiments cannot rule out the possibility that there is a relatively low density of $\mathrm{Na}$ channels present in cultures at this early stage. It is not known whether the lack of action potentials in the absence of $\mathrm{Sr}^{2+}$ and $\mathrm{Ba}^{2+}$ and the low resting potential observed in these neurons were due to membrane damage upon microelectrode penetration. Nevertheless, the presence of voltage-dependent $\mathrm{Na}$ channels in neurons in 4day cultures was suggested by the veratridine-induced cell lethality which was inhibited by TTX. Both toxins exerted their effects at concentrations comparable to those found in other cell culture systems in which $\mathrm{Na}$ action potentials have been directly demonstrated by physiological recordings (West and Catterall, 1979). Further electrophysiological investigation of the development of $\mathrm{Na}$ channels in the cultured Drosophila neurons is in progress.

Analysis of nap ${ }^{t s}$. This culture system can be employed to analyze the primary defects in Drosophila mutants with altered membrane excitability (Wu and Ganetzky, 1980; Tanouye et al., 1981; Salkoff and Wyman, 1981; Ganetzky and $\mathrm{Wu}, 1982 \mathrm{~b}$ ) and their effect on neuronal growth. The mutation napts did not appear to change the growth pattern of cultured neurons. Nor did TTX affect 
the growth. However, the conclusion of our measurements did not eliminate the possibility that the effect took place at a functional level (Archer et al., 1982) not detectable in the parameters examined in our experiments.

The decreased sensitivity of nap $^{t s}$ neurons to the lethal effect of veratridine (Fig. 10) can be explained by either a reduction in the $\mathrm{Na}$ channel density in the nerve or a change in Na channel properties, e.g., an increase in $K_{d}$ of binding to veratridine. Previous studies of $\left[{ }^{3} \mathrm{H}\right] \mathrm{TTX}$ binding (Kauvar, 1982) or $\left[{ }^{3} \mathrm{H}\right]$ saxitoxin binding (Hall et al., 1982) show that the maximal specific binding in nap ${ }^{t s}$ tissue homogenates is reduced by $40 \%$ but the $K_{d}$ for either toxin is not altered. The results appear to indicate that the number but not the property of Na channels is altered in $\operatorname{nap}^{t s}$. However, when the results from physiological studies are considered together, it appears unlikely that nap $^{t s}$ simply reduces the number of Na channels. Nerve action potential generally has a large margin of safety and only a fraction of the $\mathrm{Na}$ channels are required to produce a propagated action potential (Narahashi, 1974). The concentration of TTX (40 nM) required to block conduction in normal Drosophila axons (Wu and Ganetzky, 1980) is 8-fold greater than the $K_{d}$ (5 nM) of binding to TTX (Kauvar, 1982), indicating that more than $99 \%$ of sodium channels must be blocked before conduction fails. A mere $40 \%$ reduction in $\mathrm{Na}$ channel density cannot account for the conduction failure in $n a p^{t s}$ at only $10 \mathrm{nM}$ (2 times $K_{d}$ ) TTX (Wu and Ganetzky, 1980). Moreover, computer simulation of a Hodgkin and Huxley (1952) model axon of the dimension found in Drosophila also indicates that a $40 \%$ reduction in $\mathrm{Na}$ conductance is insufficient to explain the increase in refractory period or the high temperature conduction block observed in nap ${ }^{t s}$ axons (Wu et al., 1980). It is conceivable that a mutation can alter a functionally separate region of $\mathrm{Na}$ channels without modifying the TTX receptor site. For example, West and Catterall (1979) have demonstrated in a toxin-resistant clone of neuroblastoma cells a 40 -fold change in affinity for scorpion toxin (a cooperative agonist of veratridine) without detectable alteration in the $K_{d}$ for TTX. The drastic reduction in the sensitivity of nap $p^{t s}$ neurons to veratridine observed here is consistent with the idea that an alteration of $\mathrm{Na}$ channel function is involved. Although the present data based on cell lethality cannot provide a firm quantitative conclusion, the problem can be fully resolved by direct measurements of the veratridine-induced $\mathrm{Na}^{+}$influx or the single-channel currents associated with the $\mathrm{Na}$ channels in neurons of this culture system.

\section{References}

Archer, S. M., M. W. Dubin, and L. A. Stark (1982) Abnormal development of kitten retino-geniculate connectivity in the absence of action potentials. Science 217: 743-745.

Auerbach, A., and D. L. Barker (1981) $\left[{ }^{3} \mathrm{H}\right]$ Choline uptake and metabolism in nonsynaptic regions of a crustacean sensory nerve. J. Neurochem. 36: 1618-1658.

Benzer, S. (1973) Genetic dissection of behavior. Sci. Am. 229: 24-37.

Catterall, W. A. (1980) Neurotoxins that act on voltage-sensitive sodium channels in excitable membranes. Annu. Rev.
Pharmacol. Toxicol. 20: 15-43.

Cherbas, P., L. Cherbas, G. Demetri, M. Manteuffel-Cymborowska, C. Savakis, C. D. Yonger, and C. M. Williams (1980) Ecdysteroid hormone effects on a Drosophila cell line. In Gene Regulation by Steroid Hormones, A. K. Roy and J. H. Clark, eds., pp. 278-305, Springer-Verlag, New York.

Dudai, Y. (1977) Demonstration of an $\alpha$-bungarotoxin-binding nicotinic receptor in flies. FEBS Lett. 76: 211-213.

Fujita, S. C., A. Ferrús, S. L. Shotwell, and S. Benzer (1981) Monoclonal antibodies against the Drosophila nervous system. Soc. Neurosci. Abstr. 7: 120.

Fujita, S. C., N. Suzuki, and C. -F. Wu (1982) Antibodies distinguish cell types in primary culture of Drosophila CNS. CalTech Biology Annual Report 159, California Institute of Technology, Pasadena, CA.

Ganetzky, B., and C. -F. Wu (1982a) Indirect suppression involving behavioral mutants with altered nerve excitability in Drosophila melanogaster. Genetics 100: 597-614.

Ganetzky, B., and C. -F. Wu (1982b) Drosophila mutants with opposing effects on nerve excitability: Genetic and spatial interactions in repetitive firing. J. Neurophysiol. 47: 501514.

Goodman, C. S., and N. C. Spitzer (1981) The development of electrical properties of identified neurons in grasshopper embryos. J. Physiol. (Lond.) 313: 385-403.

Hagiwara, S., and L. Byerly (1981) Calcium channel. Annu. Rev. Neurosci. 4: 69-125.

Hall, J. C., and R. J. Greenspan (1979) Genetic analysis of Drosophila neurobiology. Annu. Rev. Genet. 13: 127-195.

Hall, L. M., and N. N. H. Teng (1975) Localization of acetylcholine receptors in Drosophila melanogaster. In Developmental Biology-Pattern Formation-Gene Regulation, D. McMahon and C. F. Fox, eds., pp. 282-289, Benjamin-Cummings Publishing Co., Menlo Park, CA.

Hall, L. M., S. D. Wilson, J. Gitschier, N. Martinez, and G. R. Strichartz (1982) Identification of a Drosophila melanogaster mutant that affects the saxitoxin receptor of the voltagesensitive sodium channel. Ciba Found. Symp. 88: 207-220.

Hamill, O. P., A. Marty, E. Neher, B. Sakmann, and F. J. Sigworth (1981) Improved patch-clamp techniques for highresolution current recording from cell and cell-free membrane patches. Pflügers Arch. 391: 85-100.

Heisenberg, M., R. Wonneberger, and R. Wolf (1978) Optomotor-blind ${ }^{\mathrm{H} 1}-\mathrm{A}$ Drosophila mutant of the lobula plate giant neurons. J. Comp. Physiol. 124: 287-296.

Hildebrand, J. G., D. L. Barker, E. Herbert, and E. A. Kravitz (1971) Screening for neurotransmitters. J. Neurobiol. 2: 231246.

Hodgkin, A. L., and A. F. Huxley (1952) A quantitative description of membrane current and its application to conduction and excitation in nerve. J. Physiol. (Lond.) 117: 500-544.

Ikeda, K., S. Ozawa, and S. Hagiwara (1976) Synaptic transmission reversibly conditioned by single-gene mutation in Drosophila melanogaster. Nature 259: 489-491.

Jan, L. Y., and Y. N. Jan (1976) Properties of the larval neuromuscular junction in Drosophila melanogaster. J. Physiol. (Lond.) 262: 189-214.

Jan, Y. N., and L. Y. Jan (1978) Genetic dissection of shortterm and long-term facilitation at the Drosophila neuromuscular junction. Proc. Natl. Acad. Sci. U. S. A. 75: 515-519.

Jan, Y. N., L. Y. Jan, and M. J. Dennis (1977) Two mutations of synaptic transmission in Drosophila. Proc. R. Soc. Lond. Biol. 198: 87-108.

Kauvar, L. M. (1982) Reduced $\left[{ }^{3} \mathrm{H}\right]$ tetrodotoxin binding in the nap $^{t s}$ paralytic mutant of Drosophila. Mol. Gen. Genet. 187: 172-173.

Moscona, A. (1961) Rotation-mediated histogenetic aggregation of dissociated cells. A quantifiable approach to cell interactions in vitro. Exp. Cell Res. 22: 455-475. 
Narahashi, T. (1974) Chemicals as tools in the study of excitable membranes. Physiol. Rev. 54: 813-889.

Nordlander, R. H., and J. S. Edwards (1969) Postembryonic brain development in the monarch butterfly, Danaus plexippus plexippus L. I. Cellular events during brain morphogenesis. Wilhelm Roux Arch. Dev. Biol. 162: 197-217.

Pak, W. L., and L. H. Pinto (1976) Genetic approach to the study of the nervous system. Annu. Rev. Biophys. Bioeng. 5: $397-448$.

Phillips, H. J., and R. V. Andrews (1959) Some protective solutions for tissue-cultured cells. Exp. Cell Res. 16: 678682.

Phillips, H. J., and J. E. Terryberry (1957) Counting actively metabolizing tissue cultured cells. Exp. Cell Res. 13: 341347.

Salkoff, L., and R. Wyman (1981) Genetic modification of potassium channels in Drosophila Shaker mutants. Nature 293: $228-230$.

Sang, J. H. (1981) Drosophila cells and cell lines. In Advances in Cell Culture, K. Maramorosch, ed., Vol. 1, pp. 125-182, Academic Press, Inc., New York.

Sattelle, D. B., L. M. Hall, and J. G. Hildebrand (1980) Receptors for Neurotransmitters, Hormones and Pheromones in Insects, Elsevier-North Holland Publishing Co., New York.

Schmidt-Nielsen, B. K., J. I. Gepner, N. N. H. Teng, and L. M. Hall (1977) Characterization of an $\alpha$-bungarotoxin binding component from Drosophila melanogaster. J. Neurochem. 29: 1013-1029.

Schneider, I. (1964) Differentiation of larval Drosophila eyeantennal discs in vitro. J. Exp. Zool. 156: 91-104.

Schneider, I., and A. B. Blumenthal (1978) Drosophila cell and tissue culture. In The Genetics and Biology of Drosophila, M. Ashburner and T. R. F. Wright, eds., Vol. IIa, pp. 265-315, Academic Press, Inc., New York.

Seecof, R. L., and R. L. Unanue (1968) Differentiation of embryonic Drosophila cells in vitro. Exp. Cell Res. 50: 654660 .

Seecof, R. L., J. J. Donady, and R. L. Teplitz (1973) Differentiation of Drosophila melanogaster neuroblasts to form ganglion-like clusters of neurons in vitro. Cell Differ. 2: 143-149.

Shields, G., and J. H. Sang (1970) Characteristics of five cell types appearing during in vilro cullure of embryonic malerial from Drosophila melanogaster. J. Embryol. Exp. Morphol. 23:
$53-69$.

Siddiqi, O., and S. Benzer (1976) Neurophysiological defects in temperature-sensitive paralytic mutants of Drosophila melanogaster. Proc. Natl. Acad. Sci. U. S. A. 73: 3253-3257.

Spitzer, N. C. (1979) Ion channels in development. Annu. Rev. Neurosci. 2: 363-397.

Strausfeld, N. J. (1976) An Atlas of an Insect Brain, pp. 13-18, 50-52, Springer-Verlag, New York.

Suzuki, N., and M. Kano (1977) Development of action poten tial in larval muscle fibers in Drosophila melanogaster. J. Cell. Physiol. 93: 383-388.

Tanouye, M. A., and C. -F. Wu (1982) Single channel studies in Drosophila mutants. CalTech Biology Annual Report 160, California Institute of Technology, Pasadena, CA.

Tanouye, M. A., A. Ferrús and S. C. Fujita (1981) Abnormal action potentials associated with Shaker complex locus of Drosophila. Proc. Natl. Acad. Sci. U. S. A. 78: 6548-6552.

West, G. J., and W. A. Catterall (1979) Selection of variant neuroblastoma clones with missing or altered sodium channels. Proc. Natl. Acad. Sci. U. S. A. 76: 4136-4140.

White, K., and D. R. Kankel (1978) Patterns of cell division and cell movement in the formation of the imaginal nervous system in Drosophila melanogaster. Dev. Biol. 65: 296-321.

Wu, C. -F., and B. Ganetzky (1980) Genetic alteration of nerve membrane excitability in temperature-sensitive paralytic mutants of Drosophila melanogaster. Nature (Lond.) 286: $814-816$.

Wu, C. -F., B. Ganetzky, L. Y. Jan, Y. -N. Jan, and S. Benzer (1978) A Drosophila mutant with a temperature-sensitive block in nerve conduction. Proc. Natl. Acad. Sci. U. S. A. 75: 4047-4051.

Wu, C. -F., B. Ganetzky, and R. W. Joyner (1980) Genetic alteration of TTX sensitivity and nerve refractory period in a mutant of Drosophila melanogaster. Soc. Neurosci. Abstr. 6: 301.

Wu, C. -F., N. Suzuki, and M.-m. Poo (1981) Cell culture and chemically induced fusion of dissociated neurons of Drosophila. Soc. Neurosci. Abstr. 7: 598.

Wu, C. -F., J. M. Berneking, and D. L. Barker (1983) Acetylcholine synthesis and accumulation in the CNS of Drosophila larvae: Analysis of shibire ${ }^{t s}$, a mutant with a temperaturesensitive block in synaptic transmission. J. Neurochem. 40: 1386-1396. 